\title{
Participatory Forest Carbon Assessment and REDD+: Learning from Tanzania
}

\author{
Kusaga Mukama, ${ }^{1}$ Irmeli Mustalahti, ${ }^{2}$ and Eliakimu Zahabu ${ }^{3}$ \\ ${ }^{1}$ District Natural Resources Office, Liwale District Council, P.O. Box 23, Liwale, Tanzania \\ ${ }^{2}$ Department of Political and Economic Studies, University of Helsinki, P.O. Box 59, 00014 Helsinki, Finland \\ ${ }^{3}$ Department of Forest Mensuration and Management, Sokoine University of Agriculture, P.O. Box 3011, Morogoro, Tanzania
}

Correspondence should be addressed to Irmeli Mustalahti, irmeli.mustalahti@helsinki.fi

Received 25 March 2011; Accepted 7 September 2011

Academic Editor: Piermaria Corona

Copyright ( $) 2012$ Kusaga Mukama et al. This is an open access article distributed under the Creative Commons Attribution License, which permits unrestricted use, distribution, and reproduction in any medium, provided the original work is properly cited.

Research initiatives and practical experiences have demonstrated that forest-related data collected by local communities can play an essential role in the development of national REDD+ programs and its' measurement, reporting, verification (MRV) systems. In Tanzania, the national REDD+ Strategy aims to reward local communities participating in forest management under Participatory Forest Management (PFM). Accessing carbon finances requires among other things, accurate measurements of carbon stock changes through conventional forest inventories, something which is rarely done in PFM forests due to its high cost and limited resources. The main objective of this paper is to discuss experiences of Participatory Forest Carbon Assessment (PFCA) in Tanzania. The study revealed that villagers who participated in PFCA were able to perform most steps for carbon assessment in the field. A key challenge in future is how to finance PFCA and ensure the technical capacity at local level.

\section{Introduction}

Reducing Emissions from Deforestation and Forest Degradation (REDD) is a financial mechanism of the United Nations Framework Convention on Climate Change (UNFCCC) which would provide developing countries with incentives to reduce carbon emissions from forests. The scope of the likely REDD+ mechanism has broadened to REDD+ to accommodate different country interests such as natural forests, protected areas and forests under community-based management. Under REDD+, developing countries that are effectively protecting their forests through conservation, sustainable forest management, and enhancement of forests carbon stock will be recognized and eligible for carbon payments.

The development of national forest monitoring and carbon accounting systems forms the basis for a future system of measurement, reporting, verification (MRV) for forestrelated emissions reductions. At the national level advanced satellite sensor technology and mapping systems will be used for the assessment of forest carbon resources and to provide a level of detail for large geographic areas in a cost- effective manner. More bottom-up community-based forest monitoring methods are developed in order to support operational forest management and monitoring. Research initiatives and practical experiences have demonstrated that forest-related data collected by local communities can play an essential role in the development of national REDD+ programs and its MRV systems [1].

At the 16th Conference of Parties (CoP 16) of the UNFCCC, held in Cancun in 2010, REDD+ mechanism and MRV activities were agreed to be financed and implemented after 2012. In this regard, Tanzania is being supported by various development partners including the government of Norway to undertake demonstration activities so that it can report on best practices. The resulting best practices and experiences will form a basis for negotiation on the future global climate change regime and provide methods that can be scaled up by other Parties under REDD+. The national REDD+ framework and the draft national REDD+ strategy for Tanzania recognize that the REDD+ initiative will provide incentives for local communities participating in forest management $[2,3]$. Accessing carbon finances through 
REDD+ requires, among other things, measurements of carbon stock changes in forests.

It has been found that carbon assessment by professionals is associated with high costs while the same work can be carried out by communities managing their forests by the use of Participatory Forest Carbon Assessment (PFCA) methods. In Tanzania, the PFCA methods were previously developed and tested under the Kyoto: Think Global Act Local project (K: TGAL). However, this testing was limited to only few localities and involved forests of small size (28-600 ha). For the wider application of the technique, some more testing was required. This study therefore tested the applicability of the developed PFCA technique in Angai Villages Land Forest Reserves (AVLFR). The AVLFR has large forest area $(139,420 \mathrm{ha})$, therefore expected to have high carbon stock potential among the participatory forest management (PFM) forests in Tanzania.

The overall objective of this paper is to discuss the PFCA technique for assessing carbon stock. Empirically, the study is based on the three selected villages around AVLFR. The research had specific objectives: (a) to assess local communities' perception and willingness to be involved in the REDD+ initiative; (b) to assess local communities' capability and the costs to carry out PFCA in three villages surrounding AVLFR; (c) to determine forest carbon stock in three villages' forest area constituting AVLFR. The key questions in this paper are how local communities perceive the PFCA and what assistance, technical and financial resources, do they need to carry out the PFCA.

\section{Case Study Area}

Participatory Forest Management (PFM) in Tanzania was introduced in 1990s following the failure of centralised forest management system. PFM is stipulated in the Forest Policy of 1998 and operationalised by the Forest Act No. 14 of 2002 [4]. The law recognizes two main types of PFM, namely, Joint Forest Management (JFM) and Community Based Forest Management (CBFM). JFM is based on a management agreement between local communities and government authorities regarding the management of central or local government forest reserves. Within JFM, forest ownership remains with the government while the local communities are duty bearers and in turn get user rights and access to some forest products and services $[4,5]$. CBFM takes place in forests on village lands that have been surveyed and registered under the provisions of the Village Land Act No. 5 of 1999 and the Forest Act No. 14 of 2002. Under CBFM, villagers take full ownership of village land forest reserves.

In Tanzania, PFM is so far implemented in 2,323 villages with coverage of 4.12 million hectares out of 35.3 million hectares of forestland in the country [6]. These statistics include Village Land Forest Reserves (VLFR) under CBFM with a total area of 2.35 million hectares in 1,460 villages. However, in spite of these achievements there are little incentives accrued by local communities compared to the costs incurred in PFM $[7,8]$. These costs include damage to their crops by animals, difficulties in patrolling vast forest boundaries without transport, and attending risks that are not compensated or rewarded. On the other hand, PFM in Tanzania has been observed to have high potential for achieving the REDD+ objectives which could provide the financial incentives required for sustainable PFM implementation [9].

This study was conducted in three selected villages of Mihumo, Ngongowele, and Ngunja that are among 13 villages surrounding the AVLFR which occupies a total area of 139,420 hectares in Liwale district, Southeast Tanzania. During recent years, the villages have been growing and District Council has advised most of the villages to be divided which means that in future there will be 24 villages instead of 13 . The case study villages cover 26,703 hectares of forest, which is equivalent to about $19 \%$ of the total AVLFR. The forest is characterized by dry miombo, closed dense forest, riverine and wet miombo with some high valuable timber species such as Brachystegia sp., Julbernardia sp., and Pterocarpus angolensis, locally known as mninga. The forest has many different tree species where 133 tree species were identified in 2004 [10]. The forest is also an important catchment area because it is the source of many rivers and streams which support not only the human population but also wildlife. Identified rivers for Mihumo village are Angai, Mihumo, and Nangula, while Nakawale and Nchonda rivers originate from forest belonging to Ngunja. Angai river is the only main river which crosses through Ngongowele VLFR. However, these rivers are seasonal and during prolonged drought most of them dry up. Angai and Mihumo rivers are the major source of water for people living in Mihumo, Kiangara, Kibutuka, Liwale B, and Mikunya villages. Villagers in Ngunja, Ngongowele, and Mihumo have access to water supply from deep and shallow water wells. However, during the dry season most of shallow wells dry up, at which point the villagers fetch water from rivers. During the dry season, some villagers in Ngunja and Ngongowele get water from Ruhuhu River which is about five kilometres from the villages centre and it originates in unreserved catchments area in Ngongowele village.

\section{Methodology}

This study is part of an action research project on the role of participatory forest management in the mitigation of and adaptation to climate change (https://blogs.helsinki.fi/ tzredd-actionresearch/). Participatory Action Research (PAR) methods were used to empower villagers to participate in forest carbon assessment as well as to study possibilities to implement REDD+ intervention in AVLFR. According to Chambers [11], PAR is an integrated approach involving the participation of community members to investigate social reality, build local skills and capacity for the purpose of increasing community independence and self sufficiency. Action research originally emerged from the conviction that science should benefit human society and not separate its research from issues of relevance and context [12].

For this study both primary and secondary methods of data collection were used based on their applicability and usefulness towards achieving the research objectives in the case study villages. In this study, Participatory Rural Appraisal (PRA) methods were used to introduce the 
TABLE 1: List of villagers selected to form VFAT for the three studied villages.

\begin{tabular}{|c|c|c|c|c|c|}
\hline Village name & No & Trainee gender & Position at the village & Age & Education \\
\hline \multirow{8}{*}{ MIhumo } & (1) & Male & VNRC chairman & 50 & Standard VII \\
\hline & (2) & Male & VNRC secretary & 21 & Standard VII \\
\hline & (3) & Female & VNRC members & 35 & Standard VII \\
\hline & (4) & Male & Community RP & 64 & Standard IV \\
\hline & (5) & Male & Community RP & 50 & Standard VII \\
\hline & $(6)$ & Male & VG member & 45 & Standard VII \\
\hline & (7) & Female & Community RP & 30 & Standard VII \\
\hline & $(8)$ & Female & VNRC member & 42 & Standard VII \\
\hline \multirow{8}{*}{ Ngongowele } & (1) & Male & Community RP & 42 & Standard VII \\
\hline & (2) & Male & Community RP & 70 & Informal Ed. \\
\hline & (3) & Male & VNRC secretary & 49 & Standard VII \\
\hline & $(4)$ & Male & Community RP & 42 & Standard VII \\
\hline & (5) & Female & Community RP & 24 & Standard VII \\
\hline & (6) & Male & VNRC member & 31 & Standard VII \\
\hline & (7) & Male & Community RP & 51 & Adult Ed. \\
\hline & $(8)$ & Female & VG member & 31 & Standard VII \\
\hline \multirow{8}{*}{ Ngunja } & (1) & Male & Community RP & 40 & Standard VII \\
\hline & (2) & Male & VNRC chairman & 29 & Standard VII \\
\hline & (3) & Male & VNRC secretary & 26 & Standard VII \\
\hline & (4) & Male & Community RP & 51 & Standard VII \\
\hline & (5) & Female & Community RP & 37 & Standard VII \\
\hline & (6) & Male & Community RP & 42 & Standard VII \\
\hline & (7) & Male & VG chairman & 51 & Standard VII \\
\hline & (8) & Female & Community RP & 49 & Standard VII \\
\hline
\end{tabular}

Note: Ed.: Education, Community RP: Community representative.

research objective and REDD+ concept through PFCA in three of the 13 villages that own and manage AVLFR. PRA methods help to shift the positioning of scientific inquiry from the researcher, who acts as a facilitator, to the participants who guide the collection of data and their local analyses [13]. PRA methods allow local people to apply their indigenous knowledge, experience, and capacity to share information $[14,15]$. Both men and women attended PRA exercises convened in each of the studied villages for two days. The group of participants included village government, Village Natural Resources Committee (VNRC) members, elders, and farmers. The PRA methods used included group discussion, pairwise ranking and scoring exercises, participatory forest mapping, a forest transect walk, participant observations, and focus group discussions.

Group discussion was used to introduce the research objectives and to collect the information on villagers' perception and their willingness to be involved in the REDD+ initiative. Participants were divided into two groups of men and women that constituted 15 participants each. The discussion of each group was guided by a checklist. The technique was used to select villagers to carry out forest carbon assessment and monitoring and to train them on the PFCA techniques. The PFCA was done using the field guide for assessing forest carbon by local communities developed by K: TGAL research project: the guide outlines steps that should be followed for assessing carbon of any forest. During the group discussions villagers were asked to select the members of the Village Forest Assessment Team (VFAT) who will participate in the PFCA. In each of the three case study villages, eight (8) villagers were selected from the village government, the VNRC, and the community at large to form the VFAT (Table 1). All members of the VFAT were permanent residents of their respective village, and most of them have standard seven educations except one elderly man from Ngongowele who had adult education, another elderly man from Mihumo who attained class four during the colonial era, and a third elderly man from Ngongowele who had informal education (Table 1). The age of the team members ranges from 21 to 70 years and $29 \%$ of them are women.

Pairwise ranking and scoring methods were employed to collect information on villagers' interest and perception regarding to the importance of the VLFR. First the researchers asked the participants to identify the importance of their VLFRs. Participants were divided into two groups of men and women. The grouping was meant to capture gender difference on the discussion issues. Thereafter matrix ranking was used to determine the villages' preference score for each perceived important factor of VLFR in each group. 
Focus group discussion method was used to learn diversities among participants in participatory forest carbon assessment as well as evaluating the whole process. The focus group discussion is a qualitative research method which can be used, for example, in the programme development and evaluation context as well planning and needs assessment situations [16]. Focus group discussion was carried out in each village with the VFATs. These participants were trained and participated in PFCA in their VLFRs. The discussion with trained villagers was guided by a checklist which focused on which steps for carbon assessment they were able or unable to do including the use of forest inventory equipments, GPS, hypsometers, and establishment of permanent sample plots. This technique enabled the researchers to learn how different villagers understood the PFCA techniques. Moreover, the technique helped the consolidation and triangulation of information acquired through participant observation regarding the capacity of trained villagers to carry out PFCA.

Since the Angai VLFRs already have a georeferenced map in place, the participants were taught to use a GPS instead of a handheld computer. Nobody among the participants had seen a GPS before as was the case in the other studies under Kyoto: TGAL in Tanzania [9]. Thus the first task was to introduce the trainees to the basic parts of eTrax GPS and its operation such as the power key, installing batteries, the zoom in/out key, the menu/find key, and the quit/page key. Also they were taught how to take GPS coordinates for marking locations such as sample plots, strata, roads, rivers, and other features in the forest.

Participants were also exposed to different forest mensuration techniques and inventory equipment as outlined in the forest inventory guide, which is inline with IPCC Good Practice Guideline [17]. They were exposed to various forest inventory equipment and their uses including hypsometers, diameter tapes, tape measures, calipers, and relascopes. Similarly they were trained on taking tree measurements like diameter at breast height $(\mathrm{DBH}$, measured at $1.3 \mathrm{~m})$, total height of different tree shape, and form on flat/slope ground. At the end of the second day, participants carried out a practical exercise, using GPS and inventory equipment in the nearby village forest.

Participatory Forest Mapping. Participatory forest mapping is a mapmaking process that attempts to make the association between forest and local communities visible by using local knowledge [18]. In this study the technique was used to provide information about different vegetation type in the VLFR as perceived by villagers. Initially, the purpose of forest stratification to forest carbon assessment and monitoring was explained to participants. Thereafter the researcher facilitated the drawing of a sketch map by participants of their respective VLFR on large sheet of paper using marker pen. They were then asked to use different colours to show the boundary of each forest type/stratum on the sketch map based on their local knowledge and experience.

Forest Transect Walk and Plot Measurements. The transect walk is an information-gathering exercise in which results can be both qualitative and quantitative [19]. In this study, the tool was used to collect information on forest stratification after participatory forest mapping. Participants were requested to draw routes on sketch map for visiting each vegetation type in the field. Participants and researcher visited each vegetation type within respective VLFR to observe similarity and differences between vegetation types in the field and those earlier drawn on the map. Site visits can establish, if what is reported is correct, true and existing [20]. Participants and researcher went around the boundary of each identified stratum/vegetation type in the field where GPS coordinates were taken for producing the final map. Furthermore the same technique was employed for a pilot survey to determine variance. Participants and researcher walked within each stratum where basal area measurements were taken to determine standard deviations and means then calculate number of plots for each stratum.

Then the number of permanent sample plots $(n)$ required in each stratum for the carbon inventory was determined using the following formula

$$
n=\frac{t^{2} \mathrm{CV}^{2}}{E^{2}},
$$

where; $\mathrm{CV}=$ Coefficient of variation $=$ standard deviation/mean $t$ is the value of $t$ obtained from the student's distribution table at $n-1$ degree of freedom of the pilot study plots at $5 \%$ probability.

According to the IPCC [17] a sampling error $(E)$ of $5 \%$ is recommended for Land Use, Land Use Change, and Forestry (LULUCF) projects. However experience has shown that under certain circumstances, a 10\% sampling error can be used to reduce costs while maintaining estimates within the precision of $\pm 10 \%$ of the mean with a $95 \%$ confidence level [9]. In this study, number of sample plots and sampling errors adopted for the different vegetation types in the case study villages are shown in Table 2.

In this study, the permanent sample plots were laid systematically with a random start. Concentric circular plot with four circles of radius of $2 \mathrm{~m}, 5 \mathrm{~m}, 10 \mathrm{~m}$, and $15 \mathrm{~m}$ was used. Major advantage of this type of plot hinges on reduced edge effects which may lead to possible counting error. In Tanzania, a similar plot size and shape is currently being used in National Forest Resources Monitoring and Assessment (NAFORMA).

After establishing permanent sample plots in the ground, the next step was to take tree variable measurements from the plots. From the different plot radii, the trees measurements taken are shown in Table 3.

Tree $\mathrm{DBH}$ was measured using tree caliper/DBH tape whereas the hypsometer was used for tree height measurements. The names of all measured trees and the counted regenerants were identified by local names by the participants. Data on each measurement were recorded along with the local tree species name on the inventory form. It was observed that most participants were able to identify the name of each tree species in their local name using their local knowledge and experience. Consequently the names of all measured trees were locally known and recorded.

Participant observation was employed in this study not only to collect information on the ability of trained villagers to carry out PFCA but also to observe the presence of disturbances in the VLFR. During the participant observations, 
TABLE 2: Number of permanent sample plots for the studied Angai VLFRs.

\begin{tabular}{|c|c|c|c|c|c|}
\hline \multirow{2}{*}{ Forest name } & \multirow{2}{*}{ Strata name } & \multirow{2}{*}{ Strata area (ha) } & \multicolumn{3}{|c|}{ Number of Plots } \\
\hline & & & $E=10 \%$ & $E=15 \%$ & Total \\
\hline \multirow[t]{2}{*}{ Ngunja } & Lowland dry miombo & 2379 & 41 & & \\
\hline & Upland dry miombo & 4247 & 39 & & \\
\hline sub total & & 6626 & 80 & & 80 \\
\hline \multirow[t]{3}{*}{ Ngongowele } & Dry miombo woodland & 8021 & 62 & & \\
\hline & Closed dense forest & 181 & & 6 & \\
\hline & Degraded riverline & 83 & & 11 & \\
\hline sub total & & 8285 & 62 & 17 & 79 \\
\hline \multirow[t]{3}{*}{ Mihumo } & Dry miombo woodland & 8169 & 78 & & \\
\hline & Wet miombo & 1695 & 13 & & \\
\hline & Closed dense forest & 1927 & & 11 & \\
\hline sub total & & 11791 & 91 & 11 & 102 \\
\hline Grand Total & & 26702 & 233 & 28 & 261 \\
\hline
\end{tabular}

the researchers participated in day-to-day activities in the field in order to gain the confidence of the persons being studied, so that their presence did not interfere with their normal activities. The researchers were actively participating in PFCA while also documenting observations on how participants were using GPS to locate transects and mark permanent plots in the field, and how they were taking tree measurement using the hypsometer and tree caliper during carbon assessment in the field. In this way, the researcher had an opportunity to compare what the villagers learned through demonstration and practice and what they were really doing in the field. In the event a villager was taking a wrong measurement, the researchers interacted with trained villagers and ensured that correct measurements and proper recording were done. Therefore the role of the researchers in this study was not only to observe but also to facilitate the process in the field when participants failed to undertake some activities regarding the carbon assessment process.

\section{Results and Discussion}

Data collected through PFCA were analyzed so as to obtain forest carbon stock in terms of tons of biomass and carbon per hectare and other stand parameters including stand density in terms of number of stems per ha $(N)$, basal area $\left(G, \mathrm{~m}^{2} / \mathrm{ha}\right)$, and volume $\left(V, \mathrm{~m}^{3} / \mathrm{ha}\right)$. Before analysis, a checklist of tree species was prepared for the three-village forest reserves studied. Botanical names were matched with the local names and each tree species was assigned a code number and arranged alphabetically for further analysis. As mentioned earlier, only sample trees were measured for total height, therefore a height-diameter equation was developed for each stratum for estimating the height of trees which were measured for $\mathrm{DBH}$ only.

For calculating tree volume and biomass, the use of local allometric equations for areas with similar geographical and vegetation types was recommended $[17,27,28]$. However in the absence of allometric equations, a common procedure is to compute stand volume and convert it to biomass. Since
TABLE 3: Plot size and tree variables measured.

\begin{tabular}{lc}
\hline Plot radius & Tree variables measured \\
\hline $2 \mathrm{~m}$ & Number of regenerants were counted \\
$5 \mathrm{~m}$ & $1 \mathrm{~cm} \leq \mathrm{dbh} \leq 10 \mathrm{~cm}$ \\
$10 \mathrm{~m}$ & $10.1 \mathrm{~cm} \leq \mathrm{dbh} \leq 20 \mathrm{~cm}$ \\
$15 \mathrm{~m}$ & $D b h \geq 20.1 \mathrm{~cm}$ \\
\hline
\end{tabular}

there is neither an equation for tree volume nor tree biomass developed for miombo woodland in Southern Tanzania, a general tree volume equation was used to calculate tree volume then converted to biomass by multiplying with a conversion factor of 0.5. Carbon was estimated from calculated biomass. According to MacDicken [29], it is assumed that $49 \%$ of biomass is carbon. The computed parameters were separated into eight diameter classes $(\mathrm{DBH}$ range $(\mathrm{cm})$ from 0 to $>70)$.

This paper intended to explore the potential of the AVLFR communities to benefit from the REDD+ initiative. It first assesses the perception and willingness of the local communities to participate in the REDD+ initiative. However, participation of the local communities in the REDD+ could be hindered by lack of information on their forest carbon stock changes. The study then assesses the capability and costs of the local communities to carry out PFCA. Lastly the forest carbon stocks in selected case study villages constituting the AVLFR are determined.

4.1. Local Community Perception and Willingness to Participate in REDD+. In Tanzania, it has been observed that households living in miombo woodlands derive more than $50 \%$ of their cash incomes from selling forest products [30]. For REDD+ intervention to be successful, it is necessary to create awareness for the purpose of introducing the new concept and assessing the communities' willingness to participate in activities. It is argued that forest communities must be informed about REDD+ initiative and have choices clearly presented to them, because changing livelihood strategies 
TABLE 4: Scoring and ranking of the importance of VLFR in studied three villages.

\begin{tabular}{|c|c|c|c|c|c|c|c|c|c|c|c|c|}
\hline \multirow{3}{*}{ Importance of forest } & \multicolumn{4}{|c|}{ Mihumo } & \multicolumn{4}{|c|}{ Ngongowele } & \multicolumn{4}{|c|}{ Ngunja } \\
\hline & \multicolumn{3}{|c|}{ Score } & \multirow[t]{2}{*}{ Rank } & \multicolumn{3}{|c|}{ Score } & \multirow[t]{2}{*}{ Rank } & \multicolumn{3}{|c|}{ Score } & \multirow[t]{2}{*}{ Rank } \\
\hline & M & $\mathrm{W}$ & A & & $\mathrm{M}$ & $\mathrm{W}$ & A & & $\mathrm{M}$ & $\mathrm{W}$ & A & \\
\hline Source of timber & 10 & 8 & 9 & 1 & 10 & 6 & 8 & 2 & 9 & 7 & 8 & 3 \\
\hline Building materials & 8 & 4 & 6 & 4 & 8 & 6 & 7 & 3 & 7 & 5 & 6 & 4 \\
\hline Beekeeping & 8 & 8 & 8 & 3 & 6 & 8 & 7 & 3 & 8 & 10 & 9 & 2 \\
\hline Carbon sequestration & 10 & 8 & 9 & 1 & 12 & 10 & 11 & 1 & 12 & 12 & 12 & 1 \\
\hline Source of fuel wood & 4 & 8 & 6 & 4 & 4 & 6 & 5 & 5 & 4 & 6 & 5 & 5 \\
\hline Traditional medicine & 2 & 4 & 3 & 6 & 2 & 4 & 3 & 6 & 2 & 1 & 2 & 6 \\
\hline $\begin{array}{l}\text { Source of food } \\
\text { (ming'oko and angadi) }\end{array}$ & 0 & 2 & 1 & 7 & 0 & 2 & 1 & 7 & 0 & 1 & 1 & 7 \\
\hline
\end{tabular}

M: Men, W: women and A: Average.

or participating in a new programme may be too risky or unattractive to them [30].

During this research, the REDD+ concept was introduced in the case study community for two consecutive days using PRA exercises in each of the three studied villages. The first day was used for the introduction of the study objectives and REDD+ concept. The researcher explained to participants the role of forests in climate change mitigation through storage and sequestering carbon from the atmosphere. The possibilities of obtaining incentives through a REDD+ project in the future for villagers who are managing forests under PFM like AVLFR were also explained. Participants were also informed about the requirements needed for them to participate in the carbon trading. The first and foremost requirement is to prove that their forest management efforts result in halting deforestation and forest degradation and eventually lead to carbon enhancement or conservation. It was explained that data needed to determine the carbon benefits resulting from their actions could be obtained through PFCA. At this point the researcher requested participants to participate in the participatory forest carbon assessment and monitoring for their VLFR. In 2009, the information about REDD+ was still a totally new and abstract idea amongst the participants in the studied villages because none of them had heard about it before.

After the REDD+ introduction, a number of issues were raised by the participants. The main concern of the participants was when the carbon fund will be available for them if they decide to participate. While some participants wanted to know exactly when the carbon funds will be available, others asked whether the price of carbon per tree is competitive to valuable timber. They were told that the price of carbon is based on tonnage of $\mathrm{CO}_{2}$ equivalent and is expected to be above US\$ 5 per $\mathrm{tCO}_{2}$; however, it is based on market price and can vary from time to time. Moreover participants from Mihumo asked if villagers would be able to harvest some valuable timber species although they would also like to participate in REDD+ initiative. They were informed that it is possible through sustainable forest management and harvesting. During the discussion, some people perceived that the REDD+ concept was designed to exclude them from accessing their VLFR, however they were assured that the design of REDD+ policy will guarantee provision of most of the benefits to the local communities.

Participants who attended PRA exercises for the first and second day were the same group of people. In each of the case study villages, participants were divided into two groups of men and women and asked to list and rank the importance of the VLFR through pairwise ranking. After completing pair wise ranking, the score for each item was determined by counting the number of times an item appeared on the table. The scores from the two groups were summed up and the average score obtained was ranked. The total score for all items in each group was 42 as illustrated in Table 4.

Both timber and carbon sequestration ranked the first priority regarding the importance of the VLFR in Mihumo while the low priority was food (ming'oko and angadi). The villagers perceived that they can reduce the harvestable wood volume to enhance carbon stock for carbon trading in future. The reason behind this was that they cannot rely only on carbon trading since they are not sure when the payment will be available. The participants in Mihumo village perceived that their VLFR has abundant valuable timber species that could be harvested for the generation of quick income from the logging when the VLFR management plan will be in place. They also expressed concern that they have been participating in forest management since 1994 without getting any financial benefit from their VLFR [31]. They pointed out that VLFR covers about $40 \%$ of their total village land, and forest under general land has been deteriorated heavily due to shifting cultivation, wildfire, and uncontrolled timber harvesting. Therefore they are looking forward to managing and harvesting their VLFR in a sustainable manner.

For Ngongowele and Ngunja, carbon sequestration was ranked high, as was the case for Mihumo, the low priority was wild food (Table 4). Participants in both villages perceived that carbon enhancement in their forests will not only enable them to gain income but will also reduce the impact of climate change in their village environment. They expressed the view that climate change had adverse impacts in their village including insufficient rainfall and prolonged drought which has led to low crop production, increased pests on cashew trees and some important rivers such as Angai and Ruhuhu drying up during the dry season. Also some short 
and deep water wells are said to be dry in the dry season, a situation which makes it necessary for the villagers to fetch water about five kilometres away. These climate change impacts are also reported elsewhere in the country $[32,33]$.

Further discussions with the participants in these villages revealed that unreserved forest under village general land in Ngongowele and Ngunja villages occupies about 73\% and $45 \%$ of the village land, respectively. Both villages also noted that the village population is low because the average forest area per person in two villages is about $15 \mathrm{ha}$ as compared to the average national figure of less than 1 ha of indigenous forest per inhabitant [34]. Villagers said that they meet most of their forest products needs from outside the AVLFR specifically in unreserved forests on general land. It was observed that the forests on general land have valuable resources which ensure the availability of forest products to the villagers. The interviewed villagers are therefore of the opinion that they could protect their already established VLFRs under the REDD+ project and could establish other buffer VLFRs in general land for logging and domestic uses. Results from PRA methods show that the food including angadi and ming'oko was ranked last followed by traditional medicines in the studied villages because these products are abundant in the general land that is near to the villages' centre while the VLFRs are far. The distance from the village centres to the forest boundaries ranges from $5 \mathrm{~km}$ to $20 \mathrm{~km}$. Traditional medicine and wild food and fuelwood received high priority only from the women group whereas the rest received high priority from both men and women. However, the enhancement of the water source was included under carbon sequestration because participants perceived that carbon enhancement would ensure the availability of forest services including water.

Moreover, PRA results in the study area revealed that the major interest of both men and women in the group is to create economic benefits from the AVLFR. The villagers noticed the need to improve forest governance and sustainable management of forest resources as one way to achieve benefits from forest resources. Access to both timber and carbon funding or markets would help to diversify livelihoods and motivate people to manage and protect forest resources. Relying on REDD+ or, for example, voluntary carbon markets could create a dependence on carbon funds or markets and reward carbon sequestration over the provision of other forest-related benefits which could also generate income.

Generally, the interest of villagers to participate in the REDD+ is stimulated by the expected incentives and the observed impacts of climate change on their village environment. Also it is likely that REDD+ project could be accepted easily in the villages which are far from town with both low population and abundance forest resources, and these were clearly contributing factors to the local people's decision to participate in an REDD+ initiative.

This result is inline with other studies elsewhere in the country where villagers' willingness to participate in forest management was stimulated by the expected benefit and their perception of negative effect on environment $[35,36]$. In the case of REDD+, the actual participation of villagers will depend on the value of carbon payment and immediate flow of carbon funds to the local communities. This is especially the case for local communities like those of AVLFRs who have been managing their valuable forest under PFM for years now without realizing any tangible benefit.

4.2. Local Community Capability and the Current and Predicted Cost of Carrying out PFCA. This section provides a summary of the ability of villagers to follow the carbon assessment procedure. It also presents the costs associated with the involvement of the villagers in the PFCA. Results from field observation and discussion with participants (Table 5) show that $90 \%, 75 \%$, and $85 \%$ of the trainees managed to identify different vegetation types in Mihumo, Ngongowele, and Ngunja VLFR, respectively. It was observed that few participants (between $40 \%$ and $30 \%$ ) were able to use GPS to mark vegetation/stratum boundary. During forest stratification, it was found that men, especially adults, are more knowledgeable on different vegetation types in the forest than youth and women. Women have limited knowledge on forest types because they are involved more in household and agricultural activities than men who are involved in hunting and logging, among other production activities. It was also revealed that neither district forest staff nor VFAT members were able to utilize the GPS coordinates for the production of stratified maps using GIS software. The reason behind this is the absence of GIS facilities at the district level. As a result, the maps were produced at the Sokoine University of Agriculture (SUA) GIS laboratory. This result is contrary to similar studies under Kyoto: TGAL elsewhere because in this study GPS was used for delineating stratum boundary instead of a handheld computer $[9,37]$.

On the pilot survey for determining sample size, results in Table 5 show that a high number of participants $(85 \%$ in Mihumo, $75 \%$ in Ngongowele, and $80 \%$ in Ngunja) managed to use the relascope for measuring basal area in their VLFR. On the other hand all of them lacked knowledge on calculating the sample size from the collected data. Therefore data analysis for determining sample size was the responsibility of the researcher as was similarly reported in other studies under Kyoto: TGAL [9, 37, 38].

Prior to locating permanent sample plots on the ground, planning for fieldwork including transects and plot layout on the map was done by the researcher as was in the case of similar studies elsewhere $[9,38]$. It was observed that all participants in each village were able to lay down 261 permanent sample plots in the studied VLFRs. However it was found that only $70 \%, 60 \%$, and $65 \%$ of participants in Mihumo, Ngongowele, and Ngunja respectively, managed to take coordinates of the plot centre using GPS. Furthermore it was observed that on average only $40 \%$ of all participants were able to navigate through transect line from one plot to another.

Regarding measurements from the permanent plots, results in Table 5 show that $95 \%$ of participants in both Mihumo and Ngunja village succeeded in taking tree diameter at breast height $(\mathrm{DBH})$ measurement using calipers as compared to $85 \%$ in Ngongowele. The variation in these villages is probably due to the fact that individuals from, 
TABLE 5: Percent of participants who were able to do various steps for carbon assessment.

\begin{tabular}{|c|c|c|c|c|}
\hline \multirow{2}{*}{ No. } & \multirow{2}{*}{ Steps for carbon assessment } & \multicolumn{3}{|c|}{ Participants percent } \\
\hline & & Mihumo & Ngongowele & Ngunja \\
\hline 1.0 & Stratification & & & \\
\hline 1.1 & Identifying different vegetation type & 90 & 75 & 85 \\
\hline 1.2 & $\begin{array}{l}\text { Marking vegetation type/stratum boundary with } \\
\text { GPS }\end{array}$ & 40 & 30 & 35 \\
\hline 1.3 & GIS process to produce forest map and its strata. & None & None & None \\
\hline 2 & Piloting for determining sample size & & & \\
\hline 2.1 & Taking basal area measurements using relascope & 85 & 75 & 80 \\
\hline 2.1 & Calculating sample size from the collected data & None & None & None \\
\hline 3.0 & Locating permanent sample plots on the map & & & \\
\hline 3.1 & $\begin{array}{l}\text { Determining distance between transects and } \\
\text { sample plots. }\end{array}$ & None & None & None \\
\hline 3.2 & $\begin{array}{l}\text { Locating transect line and sample plots on the } \\
\text { map }\end{array}$ & None & None & None \\
\hline 4.0 & Locating permanent sample plots on the ground & & & \\
\hline 4.1 & $\begin{array}{l}\text { Navigating through transect line with GPS in the } \\
\text { forest }\end{array}$ & 45 & 35 & 40 \\
\hline 4.2 & $\begin{array}{l}\text { Marking permanent sample plots on the ground } \\
\text { using GPS }\end{array}$ & 70 & 60 & 65 \\
\hline 4.3 & Establishment of permanent plot on the ground & 100 & 100 & 100 \\
\hline 5.0 & Measurements taken from permanent sample plots & & & \\
\hline 5.1 & Measuring tree $\mathrm{DBH}$ using caliper & 95 & 85 & 95 \\
\hline 5.2 & Measuring tree height using hypsometer & 38 & 25 & 38 \\
\hline 5.3 & Tree identification in local name & 100 & 100 & 100 \\
\hline 6 & Calculating carbon stock from the collected data & None & None & None \\
\hline
\end{tabular}

for example, different genders and age groups have different knowledge and understanding. It was revealed that only $38 \%$ of the participants in both Mihumo and Ngunja managed to take tree height measurement using hypsometer while $62 \%$ of the remaining participants failed to use it. Even in the group discussions with key informants, participants expressed concern that some of them were not able to use GPS and hypsometer during the carbon assessment. This result is contrary to Zahabu [9] who reported that among other procedures villagers were able to use handheld computer and hypsometer. The difference might be attributed to limited training time adopted in the study; in the previous case study villages under Kyoto: TGAL project, the learning-bydoing process was ongoing for four consecutive years while in this study only one training and assessment period has thus far been done. The short research period was therefore not enough for participants to gain sufficient knowledge and experience in using the GPS and hypsometer. For this reason, they have appealed for more training and technical assistance from the district council and development partners to increase their knowledge and become competent on using the mentioned equipment. Besides the training, other assistance that is required includes field uniforms and gumboots, transport, inventory equipment, and a fund for allowances.

Results also show that all of participants in each village were able to identify all tree/shrub species encountered dur- ing carbon assessment because they have local knowledge regarding tree species identification. Zahabu [9] reported that local community knowledge is important in identifying trees species and various vegetation types in the forests. Regarding data analysis, the data were analyzed by the researcher, and the carbon assessment results were communicated to villagers through group discussion where village leaders and members of VFAT attended.

Table 6 indicates the main steps for PFCA with their respective costs for each VLFRs. The total cost spent to accomplish PFCA in Mihumo, Ngongowele, and Ngunja VLFRs was Tsh.8, 595,181/=, 7,303,481/= and 7,222,481/= equivalent to US $\$ 6,612,5,618$ and 5,556 , respectively. This is equivalent to the cost per hectare for Mihumo, Ngongowele, and Ngunja of TShs.729/=, 882/=, and 1,090/= equivalent to US $\$ 0.56, \$ 0.68$ and $\$ 0.84$, respectively. It was observed that although the total cost was increasing with increasing forest area, the trend is vice versa for the cost per hectare.

The cost per hectare in other studies under Kyoto:TGAL research in Tanzania for the first year of carbon assessment ranged between $\$ 5$ and $\$ 53$ for large forest (1020 ha) and small forest area (28.5 ha), respectively [9]. In this study, the observed cost per hectare is much lower compared to those reported by Zahabu [9]. Also the cost per hectare is much lower than other studies in India where the first year's work was estimated at $\$ 3$ per hectare and the cost of the professional team was done at $\$ 5.50$ per hectare [37]. The 
TABLe 6: Transaction cost for PFCA.

\begin{tabular}{|c|c|c|c|c|c|c|c|c|c|}
\hline \multirow{4}{*}{ Components } & \multicolumn{9}{|c|}{ Village forest name } \\
\hline & \multicolumn{3}{|c|}{ Mihumo (11,792 ha) } & \multicolumn{3}{|c|}{ Ngongowele ( 8,285 ha) } & \multicolumn{3}{|c|}{ Ngunja (6,626 ha) } \\
\hline & \multirow{2}{*}{ No. of days } & \multicolumn{2}{|c|}{ Cost } & \multirow{2}{*}{ No. of days } & \multicolumn{2}{|c|}{ Cost (Tsh.) } & \multirow{2}{*}{ No. of days } & \multirow{2}{*}{ Tsh. "000" } & \multirow{2}{*}{$\begin{array}{l}\text { Cost } \\
\text { US\$ }\end{array}$} \\
\hline & & Tsh. “000” & US\$ & & Tsh. “000” & US\$ & & & \\
\hline $\begin{array}{l}\text { Training, } \\
\text { stratification, } \\
\text { and piloting }\end{array}$ & 5 & 950 & 731 & 5 & 758 & 583 & 5 & 742 & 571 \\
\hline $\begin{array}{l}\text { Inventory } \\
\text { equipments }\end{array}$ & & 1,394 & 1,072 & & 1,394 & 1,072 & & 1,394 & 1,072 \\
\hline $\begin{array}{l}\text { Forest carbon } \\
\text { assessment }\end{array}$ & 17 & 5,052 & 3,886 & 10 & 4,252 & 3,271 & 10 & 4,187 & 3,221 \\
\hline $\begin{array}{l}\text { Data analysis } \\
\text { and reporting }\end{array}$ & 20 & 1,200 & 923 & 15 & 900 & 692 & 15 & 900 & 692 \\
\hline Total & 42 & 8,595 & 6,612 & 30 & 7,303 & 5,618 & 30 & 7,222 & 5,556 \\
\hline Cost/ha & & 0.72 & 0.56 & & 0.88 & 0.68 & & 1.09 & 0.8 \\
\hline
\end{tabular}

plausible explanation for this variation in cost per hectare is that the studied VLFRs are too large ( $>6000 \mathrm{ha}$ ) compared to forest area of the previous studies $(<600 \mathrm{ha})$.

In all three villages, participants complained about the payments they received as compensation for their participation in the PFCA. Concerning the budget, villagers need to be involved in budgeting process for carbon monitoring in future. They also want that the grant for PFCA be disbursed to village government account as this will increase the level of people's participation; community members should participate in decision making, implementation, benefit sharing, and evaluation in order to own the process of development. For example, in order to learn from the process participants need to know and experience the costs of PFCA; otherwise they will not be able to weigh them against the potential benefits. Participants were only discontent with Tshs. 5,000/= per day for each person as incentive for their participation in forest carbon inventory in their village forests.

Forest carbon assessment is difficult and dangerous because the teams need to walk for a long time (at least $15 \mathrm{~km}$ per day) in the forest with a risk of being attacked by wild animals like elephants and lions. Also, when required to camp in the forests, the costs are higher compared to their earnings per day from the carbon assessment. Most participants are heads of families with farming and daily bread-earning responsibilities so their participation in carbon assessment prevents them from farming and other income generating activities compared to their fellow villagers. Based on the above reasons and their experience on carbon assessment, participants from all villages proposed to be paid Tsh. 15,000/= per day as an incentive for their participation in carbon assessment in the future. However, Zahabu [9] reported that the trainees were paid $\$ 5$ which is equivalent to Tsh.6,550/= per day per trainee and this was appreciated in that study group. The difference is apparently because the payments in the previous studies were based on the government rate for hiring local labourers in the village, while the villagers' proposal in this study is based on opportunity costs and risks.
Further, this study involved camping in the forests, a practice that was not done in the previous studies.

Table 7 shows that total cost for the PFCA is predicted to increase to $22 \%, 19 \%$, and $12 \%$ for Mihumo, Ngongowele, and Ngunja VLFR, respectively, due to an increase in participants allowances from Tsh. 5000/= to $15,000 /=$ and the need for more training. However this increase will not add much to the per hectare costs since these are much lower compared to other studies. The main challenge to this proposed rate is the availability of funds when the village governments will need to do carbon monitoring in the future. According to the village leaders, the village government lacks its own source of income that could be used for paying villagers to conduct carbon assessment.

4.3. Forest Carbon Stock in Three Village Forest Reserves. A total of 134 tree species were identified in the three studied village forest reserves including 93, 86, and 72 tree species for Mihumo, Ngongowele, and Ngunja village forest reserves. The number of tree species identified in this study is consistent with previous studies at AVLFR [10] and elsewhere in Tanzania [39-43]. Forest stand parameters such as number of stems, basal area, volume, biomass, and carbon per hectare in each stratum for the studied VLFRs are summarized in Table 8 . The number of stems per hectare across the studied VLFRs in different strata ranged between $639 \pm 215$ and $903 \pm 136$ with the exception of the closed dense forest and encroached river basin (Table 8).

These results are comparable with other studies in miombo woodland and elsewhere in the country as shown in Table 10. However, the observed stems per hectare among the mentioned strata are lower than that reported in other studies in Duru-Haitemba, Kitulangaro GFR, and Kitulangalo Sokoine University of Agriculture Training Forest Reserve (KSUATFR) $[9,22,24]$. This could be attributed to the frequent occurrence of intense forest fires in the studied VLFR which affects the growth of young trees so the forests are moderately open. Moreover during the study, forest fires 
TABle 7: Predicted cost for PFCA.

\begin{tabular}{|c|c|c|c|c|c|c|c|c|c|}
\hline \multirow{4}{*}{ Components } & \multicolumn{9}{|c|}{ Village forest name } \\
\hline & \multicolumn{3}{|c|}{ Mihumo (11,792 ha) } & \multicolumn{3}{|c|}{ Ngongowele (8,285 ha) } & \multicolumn{3}{|c|}{ Ngunja $(6,626$ ha) } \\
\hline & No of dave & Cost & & No of dave & Cost & & No of $\mathrm{d}$ & Cost & \\
\hline & No. or cays & Tsh. “000” & US\$ & & Tsh. “000” & US\$ & No. O1 de & Tsh. "000" & US\$ \\
\hline $\begin{array}{l}\text { Training on uses } \\
\text { of inventory } \\
\text { equipments }\end{array}$ & 5 & 950 & 731 & 5 & 758 & 583 & 5 & 742 & 571 \\
\hline $\begin{array}{l}\text { Inventory } \\
\text { equipments }\end{array}$ & & 1,394 & 1,072 & & 1,394 & 1,072 & & 1,394 & 1,072 \\
\hline $\begin{array}{l}\text { Forest carbon } \\
\text { assessment }\end{array}$ & 17 & 6,959 & 5,353 & 13 & 5,651 & 4,347 & 10 & 5,070 & 3,900 \\
\hline $\begin{array}{l}\text { Data analysis } \\
\text { and reporting }\end{array}$ & 20 & 1,200 & 923 & 15 & 900 & 692 & 15 & 900 & 692 \\
\hline Total & 42 & 10,503 & 8,079 & 33 & 8,703 & 6,694 & 30 & 8,106 & 6,235 \\
\hline Cost/ha & & 0.89 & 0.69 & & 1.05 & 0.81 & & 1.22 & 0.9 \\
\hline
\end{tabular}

TABLE 8: Stand parameters for three studied VLFR.

\begin{tabular}{|c|c|c|c|c|c|c|}
\hline Forest name & Vegetation type & $N$ & $G\left(\mathrm{M}^{2} / \mathrm{ha}\right)$ & $V\left(\mathrm{M}^{3} / \mathrm{ha}\right)$ & Biomass (t/ha) & Carbon (t/ha) \\
\hline \multirow{3}{*}{ Mihumo } & Dry miombo & $\begin{array}{c}870 \pm 119 \\
(14)\end{array}$ & $\begin{array}{l}9.8 \pm 0.78 \\
(7.99)\end{array}$ & $\begin{array}{c}68.95 \pm 10.20 \\
(14.79)\end{array}$ & $\begin{array}{l}34.48 \pm 5.1 \\
(14.79)\end{array}$ & $\begin{array}{c}17.24 \pm 2.55 \\
(14.79)\end{array}$ \\
\hline & Wet miombo & $\begin{array}{l}639 \pm 215 \\
(34)\end{array}$ & $\begin{array}{c}9.21 \pm 2.37 \\
(25.77)\end{array}$ & $\begin{array}{c}67 \pm 30.83 \\
(46.02)\end{array}$ & $\begin{array}{c}33.5 \pm 15.42 \\
(46.02)\end{array}$ & $\begin{array}{c}16.75 \pm 7.71 \\
(46.02)\end{array}$ \\
\hline & Closed forest & $\begin{array}{c}2824 \pm 237 \\
(8)\end{array}$ & $\begin{array}{c}29.23 \pm 4.83 \\
(16.5)\end{array}$ & $\begin{array}{c}339.59 \pm 67.86 \\
(19.98)\end{array}$ & $\begin{array}{c}169.79 \pm 33.71 \\
(19.98)\end{array}$ & $\begin{array}{c}84.89 \pm 16.85 \\
(19.98)\end{array}$ \\
\hline \multirow{3}{*}{ Ngongowele } & Dry miombo & $\begin{array}{c}731 \pm 138 \\
(19)\end{array}$ & $\begin{array}{c}11.37 \pm 0.98 \\
(8.58)\end{array}$ & $\begin{array}{c}77.46 \pm 10.02 \\
(12.93)\end{array}$ & $\begin{array}{c}38.73 \pm 5.01 \\
(12.93)\end{array}$ & $\begin{array}{c}19.36 \pm 2.51 \\
(12.93)\end{array}$ \\
\hline & Closed forest & $\begin{array}{c}3305 \pm 1402 \\
(42)\end{array}$ & $\begin{array}{c}16.17 \pm 5.24 \\
(32.39)\end{array}$ & $\begin{array}{c}166.94 \pm 88.69 \\
(53.13)\end{array}$ & $\begin{array}{c}83.47 \pm 44.35 \\
\quad(53.13)\end{array}$ & $\begin{array}{c}41.73 \pm 22.17 \\
(53.13)\end{array}$ \\
\hline & $\begin{array}{l}\text { Encroached river } \\
\text { basin }\end{array}$ & $\begin{array}{c}253 \pm 210 \\
\quad(83)\end{array}$ & $\begin{array}{c}5.85 \pm 1.73 \\
(29.59)\end{array}$ & $\begin{array}{c}28.82 \pm 9.29 \\
\quad(32.25)\end{array}$ & $\begin{array}{c}14.41 \pm 4.65 \\
(32.25)\end{array}$ & $\begin{array}{c}7.2 \pm 2.32 \\
(32.25) \\
\end{array}$ \\
\hline \multirow[t]{2}{*}{ Ngunja } & $\begin{array}{l}\text { Lowland dry } \\
\text { miombo }\end{array}$ & $\begin{array}{c}903 \pm 136 \\
(15)\end{array}$ & $\begin{array}{l}9.82 \pm 0.92 \\
\quad(9.42)\end{array}$ & $\begin{array}{c}73.49 \pm 9.99 \\
(13.59)\end{array}$ & $\begin{array}{c}36.75 \pm 5 \\
(13.59)\end{array}$ & $\begin{array}{c}18.37 \pm 2.2 .5 \\
(13.59)\end{array}$ \\
\hline & Upland dry miombo & $\begin{array}{c}795 \pm 155 \\
(19)\end{array}$ & $\begin{array}{c}9.98 \pm 0.96 \\
(9.67)\end{array}$ & $\begin{array}{c}72.05 \pm 11.63 \\
(16.13)\end{array}$ & $\begin{array}{c}36.03 \pm 5.81 \\
(16.13)\end{array}$ & $\begin{array}{c}18.02 \pm 2.9 \\
(16.13)\end{array}$ \\
\hline
\end{tabular}

The figures in brackets indicate precision level of estimates, that is, confidence intervals as percentage of mean value.

were observed in most strata. The number of stems per hectare in closed dense forest is 2824 and 3305 in Ngongowele and Mihumo VLFRs, respectively. The observed number of stems per hectare in these strata is not only relatively higher than that observed among strata in the studied VLFRs but also with other studies elsewhere in Tanzania (Table 9). The plausible reason for this would be attributed by absence of forest disturbance and the nature of the forests themselves.

The encroached river basin not only has a low stem density compared to the other strata in the three VLFRs but also compared with results reported in miombo elsewhere $[9,22,24]$. The plausible explanation for this is that farmers from Ngongowele have been clearing trees along Angai river basin (Nandete) for agriculture purposes.

Table 10 shows that on average the carbon stock in wet and dry miombo strata including lowland and upland in Ngunja VLFR ranged from $16.75 \mathrm{tC} /$ ha to $19.36 \mathrm{tC} / \mathrm{h}$. There are numbers of reasons for low carbon stock in these strata including previous timber harvesting before it ceased in 2005 when the 13 Angai villages got legal land rights for the AVLFR, frequent high intensity fires, and the nature of the forests themselves. The closed forests strata were found to have high value of carbon stock, $(84.89 \mathrm{tC} / \mathrm{ha}$ and $41.73 \mathrm{tC} / \mathrm{ha}$ in Mihumo and Ngongowele VLFR, resp.). The reason behind this high value is the presence of old growth Brachystegia microphylla trees and a lack of any human disturbance. The least amount of carbon stock found in the study was $7.2 \mathrm{tC} / \mathrm{ha}$ in the encroached river basin due to clearance of forest for rice farming.

Results in Table 10 also shows that the observed storage of carbon stock in Mihumo, Ngongowele, and Ngunja VLFR was 332.81-266.4 MgC, 163.42-139.01 MgC, and 120.23102.56 MgC, respectively. The Mihumo VLFR stores considerably more carbon than the other two reserves. Although 
TABLE 9: Stand parameters from various studies in miombo woodland.

\begin{tabular}{|c|c|c|c|c|c|c|}
\hline Author & Forest Name & $N$ & $G\left(\mathrm{M}^{2} / \mathrm{ha}\right)$ & $V\left(\mathrm{M}^{3} / \mathrm{ha}\right)$ & $\begin{array}{c}\text { Biomass } \\
(\mathrm{t} / \mathrm{ha})\end{array}$ & $\begin{array}{c}\text { Carbon } \\
(\mathrm{t} / \mathrm{ha})\end{array}$ \\
\hline Zahabu (2008) [9] & KSUATFR & $628-694$ & $7.9-9.9$ & $55.3-74.8$ & $35.2-45.9$ & $17.6-22.9$ \\
\hline Zahabu (2008) [9] & Kimunyu & $701-845$ & $7.9-8.8$ & $72.4-88.2$ & $39.7-45$ & $19.86-22.5$ \\
\hline Njana (2008) [21] & Urumwa FR & 583 & 8.54 & 58.41 & - & - \\
\hline Malimbwi (2003) [22] & Duru Haitemba & 1988 & 12.41 & 97.32 & - & - \\
\hline Zahabu (2001) [23] & KSUATFR & 619 & 10.2 & 78 & - & - \\
\hline $\begin{array}{l}\text { Chamshama et al. } \\
\text { (2004) [24] }\end{array}$ & $\begin{array}{l}\text { Kitulangalo } \\
\text { GFR }\end{array}$ & 1085 & 9 & 76 & 43.56 & \\
\hline $\begin{array}{l}\text { Malimbwi and Mugasha } \\
\text { (2002) [25] }\end{array}$ & Handen Hill & 355 & 11.2 & 108.99 & - & - \\
\hline $\begin{array}{l}\text { Chamshama et al. } \\
(2004)[24]\end{array}$ & KSUATFR & 1027 & 8.95 & 76.02 & 41.40 & \\
\hline Nuru et al. (2009) [26] & Urumwa FR & 642 & 8.7 & 59.73 & & \\
\hline
\end{tabular}

TABLE 10: Total carbon stock in each VLFR.

\begin{tabular}{|c|c|c|c|c|c|}
\hline \multirow{2}{*}{ Forest name } & \multirow{2}{*}{ Stratum } & \multirow{2}{*}{ Area (ha) } & \multirow{2}{*}{$\begin{array}{l}\text { Carbon stock } \\
(\mathrm{tC} / \mathrm{ha})\end{array}$} & \multicolumn{2}{|c|}{ Total carbon stock (Mega tonnes of Carbon) } \\
\hline & & & & Upper limit & Lower limit \\
\hline \multirow[t]{2}{*}{ Ngunja } & Lowland dry miombo & 2379 & $18.37 \pm 2.25$ & 43.7 & 38.35 \\
\hline & Upland dry miombo & 4247 & $18.02 \pm 2.9$ & 76.53 & 64.21 \\
\hline Total & & & & 120.23 & 102.56 \\
\hline \multirow[t]{3}{*}{ Ngongowele } & Dry miombo & 8021 & $19.36 \pm 2.51$ & 155.28 & 135.15 \\
\hline & Closed forest & 181 & $41.73 \pm 22.17$ & 7.55 & 3.54 \\
\hline & $\begin{array}{l}\text { Encroached river } \\
\text { basin }\end{array}$ & 83 & $7.2 \pm 2.32$ & 0.59 & 0.4 \\
\hline Total & & & & 163.42 & 139.01 \\
\hline \multirow[t]{3}{*}{ Mihumo } & Dry miombo & 8169 & $17.24 \pm 2.55$ & 140.83 & 120 \\
\hline & Wet miombo & 1695 & $16.75 \pm 7.71$ & 28.40 & 15.32 \\
\hline & Closed forest & 1927 & $84.89 \pm 16.85$ & 163.58 & 131.11 \\
\hline Total & & & & 332.81 & 266.43 \\
\hline
\end{tabular}

the VLFRs studied here have low carbon stock per hectare, the total amount of carbon they store is large because of their large areas (Table 10). It is clear that if the forest would be managed properly, the amount of carbon sequestration would be sufficient for carbon trading because of the total area under protection.

\section{Conclusions}

The experience of this study shows that the willingness of the villagers to participate in REDD+ initiative is motivated by the expected income they would like to receive from carbon enhancement activities and also by their perception of the negative effects that climate change might have on their environment. The study also revealed that in the long run, the actual commitment and participation of villagers in an REDD+ project will depend on a timely flow of carbon payments to the participating communities at the project level.

The present study demonstrates that PFCA is a useful technique at the project level because it ensures that the local communities' knowledge and experience can deliver carbon data at low cost through their participation. However, local communities' ability to carry out carbon assessments independently will require not less than two training periods for two consecutive years on PFCA techniques to allow them to properly understand the use of GIS and inventory equipment incorporated in the methodology. The experience gained in this study reveals that not all participants were able to neither develop a VLFR map from GPS coordinates nor analyze the collected data from the carbon inventory. Therefore the successful and sustainable implementation of PFCA at project level will depend on collaboration between local communities and a facilitating organization (NGO/District Council) for GIS and carbon data analysis. The technique tested here can be applied throughout PFM areas to generate carbon data, however, the training and methods need to be based on the local context and knowledge and conditions in local communities.

Findings from this study show that generally the case study VLFRs store carbon stock per hectare similarly to other miombo forests in Tanzania. On average the carbon stock in 
wet and dry miombo strata including lowland and upland in Ngunja VLFR ranged from $16.75 \mathrm{tC} /$ ha to $19.36 \mathrm{tC} / \mathrm{ha}$. Although the studied VLFRs have low carbon stock per hectare, they store a large amount of total carbon stock (ranging from 626.46 MgC to $508 \mathrm{MgC}$ for upper and low limit, resp.) due to their vast area (26 $703 \mathrm{ha})$. This ensures significant carbon stock and sequestration for carbon in future. Moreover medium tree diameters accounted for $60 \%$ of the average total carbon stock in all strata except for closed forest and encroached river basin. The possible reason for this distribution would be past harvesting of the large diameter trees in the past for timber businesses and the nature of the forests themselves. The trees of large diameters are responsible for $90 \%$ and $70 \%$ of the average total carbon stock in closed forest strata in Mihumo and Ngongowele respectively.

Under an REDD+ project, sustainable harvesting could be encouraged. However, proper management of carbon stock can be achieved only if the timber harvesting level is determined through the forest carbon assessment in permanent sample plots. This study demonstrates that timber harvesting could be conducted in all strata except for closed forest, wet miombo, and degraded river basin including a strip of twenty meters from the river bank of Angai, Nakawale, and Nangula. The reason is the unavailability of valuable timber species in these strata and water source protection for animal and human uses. The assessment demonstrated in this study will enable villagers to understand their forest growth potential and establish sustainable timber harvesting levels and at the same time allow carbon stock enhancement. For carbon management purposes in the case study, there is a need to conduct carbon monitoring consecutively before establishing timber harvesting level. Moreover local communities should harvest old grown trees and promote long-term regeneration of high carbon species.

It is apparent that the carbon stock stored in AVLFR faces threats from illegal timber harvesting, wildfires, and conversion of forest to agricultural use. If the observed carbon stocks are to be conserved and enhanced for the carbon payments, it is important that villagers be supported to take action to stop the prevailing disturbance inside AVLFR. A forest fire management programme is necessary because vast areas of AVLFR are torched every year during late dry season. In fact, management of these fires is an attractive option for enhancing carbon stock and reducing trace gas emission. Village governments and VNRCs should make a concerted effort to stop the prevailing forest disturbances in the AVLFR not only by increasing the number of patrols but also by training and educating community members on issues related to early burning and forest fire management. Moreover village governments could provide incentives/payments and food to patrolling teams.

There is a need for national level among the various development partners to recognize PFCA as an appropriate technique for carbon assessment in PFM forests and mainstream the technique into the PFM process to ensure sustainable availability of inventory data for both carbon credits and forest management planning. Moreover at national level, inventories and MRV systems should be reviewed to capture carbon data from REDD+ projects. A key challenge in future is how to finance PFCA in various REDD+ project areas and ensure the technical capacity at local level. Therefore central governments as well as development partners are requested to provide support to local communities to ensure sustainable management of carbon stock areas such as AVLFR. Both technical and financial support should continue in the following years until communities can independently carry out the PFCA and finance it for example through the REDD+ payments.

\section{Acknowledgments}

This paper was presented at a conference called Reframing sustainability? Climate Change and North-South Dynamics, 10th-11th February, 2011, Helsinki, Finland. The authors want to thank Academy of Finland for funding this study. Grateful acknowledgement to the Liwale District Council and District Executive Director (DED), Mr. Moya, for permission to carry out this study. they also appreciate the assistance of Mr. Kilowoko, Mr. Mbujiro, Mr. Mzui, Mr. Namwewe, and Mr. Amanzi. they would like to express their appreciation for the cooperation and endurance shown by villagers who participated in carbon assessment in Mihumo, Ngongowele, and Ngunja and who worked tirelessly in harsh conditions and a threatening environment.

\section{References}

[1] F. Danielsen, M. Skutsch, N. D. Burgess et al., "At the heart of REDD+: a role for local people in monitoring forests?" Conservation Letters, vol. 4, no. 2, pp. 158-167, 2011.

[2] United Republic of Tanzania (URT), "Draft: preparing for the REDD initiative in Tanzania. A synthesized consultative report for REDD task force in Tanzania," 2009, http://www.reddtz .org/.

[3] United Republic of Tanzania (URT), "Final draft: forest carbon partnership facility (FCPF), readiness preparation proposal (R-PP)," 2010, http://www.reddtz.org/.

[4] United Republic of Tanzania (URT), The Forest Act no. 14, Ministry of Natural Resources and Tourism. Government Printer, Dar es Salaam, Tanzania, 2002.

[5] L. A. Wily, Villagers as Forest Managers and Government: "Learning to Let Go". The Case of Duru-Haitemba and Mgori Forests in Tanzania, Forest participation Series 9, International Institute for Environment and Development (IIED), London, UK, 1997.

[6] United Republic of Tanzania (URT), Participatory Forest Management in Tanzania. Facts and Figures, Ministry of Natural Resources and Tourism, Forestry and Beekeeping Division, Dar es Salaam, Tanzania, 2008.

[7] R. E. Malimbwi and E. Zahabu, "REDD Experience in Tanzania," in REDD, Forest Governance and Rural Livelihoods: The Emerging Agenda, O. Springate-Baginski and E. Wollenberg, Eds., pp. 109-134, CIFOR, Bogor, Indonesia, 2010.

[8] I. Mustalahti and J. F. Lund, "Where and how can participatory forest management succeed? Learning from Tanzania, Mozambique, and Laos," Society and Natural Resources, vol. 23, no. 1, pp. 31-44, 2010.

[9] E. Zahabu, Sinks and sources: a strategy to involve forest communities in Tanzania in global climate policy, Ph.D. thesis, University of Twente, Enschede, The Netherlands, 2008. 
[10] S. Dondeyne, A. Wijffels, L. B. Emmanuel, J. Deckers, and M. Hermy, "Soils and vegetation of Angai forest: ecological insights from a participatory survey in South Eastern Tanzania," African Journal of Ecology, vol. 42, no. 3, pp. 198-207, 2004.

[11] R. Chambers, "Beyond whose reality counts? New methods we now need. Studies in culture," Journal of Organisations and Societies, vol. 4, no. 2, pp. 279-301, 1998.

[12] H. Bradbury and P. Reason, "Action research: an opportunity for revitalising research purpose and practices," Journal of Qualitative Social Work, vol. 2, no. 2, pp. 156-175, 2003.

[13] J. A. Ericson, "A participatory approach to conservation in the Calakmul Biosphere Reserve, Campeche, Mexico," Landscape and Urban Planning, vol. 74, no. 3-4, pp. 242-266, 2006.

[14] G. C. Kajembe, Indigenous Management Systems as a Basis for Community Forestry in Tanzania: A Case Study of Dodoma Urban and Lushoto Districts, Tropical Resource Management Paper no. 6, Wageningen Agricultural University, Wageningen, The Netherlands, 1994.

[15] I. Mustalahti, "Sustaining participatory forest management: case study analyses of forestry assistance from Tanzania, Mozambique, Laos and Vietnam," Small-Scale Forestry, vol. 8, no. 1, pp. 109-129, 2009.

[16] R. Krueger and M. A. Casey, Focus Groups: A Practical Guide for Applied Research, Sage Publication, Thousand oaks, Calif, USA, 3rd edition, 2000.

[17] IPCC, Good Practice Guidance for Land Use, Land-Use Changes and Forestry, Institute of Global Environmental Strategies, Kanagawa, Japan, 2003.

[18] S. Di Gessa, "Participatory mapping as a tool for empowerment: experience and Lessons learned from the ILC network," 2008, http://www.landcoalition.org/pdf/08_ILC_Participatory _Mapping_Low.pdf.

[19] R. Kumar, Research Methodology: A Step-by Step Guide for Beginners, Sage Publication, London, UK, 2nd edition, 2005.

[20] D. Narayan, "What is participatory research?" in Toward Participatory Research, pp. 17-30, World Bank, Washington, DC, USA, 1996.

[21] M. A. Njana, Arborescent species diversity and stocking in the Miombo woodland of Urumwa Forest Reserve and their contribution to livelihoods, Tabora, Tanzania, M.S. thesis, Sokoine University of Agriculture, Morogoro, Tanzania, 2008.

[22] R. E. Malimbwi, Inventory reports of Ayasanda, Bubu, Duru, Endagwe, Gidas Endanachan, Hoshan and Riroda Village Forest Reserves in Babati Manyara, Tanzania, Land Management Programme, Babati District Council, Manyara, Tanzania, 2003.

[23] E. Zahabu, Impact of charcoal extraction on the Miombo Woodlands: The case of Kitulangalo Area, Tanzania, M.S. thesis, Sokoine University of Agriculture, Morogoro, Tanzania, 2001.

[24] S. A. O. Chamshama, A. G. Mugasha, and E. Zahabu, "Stand biomass and volume estimation for Miombo woodlands at Kitulangalo, Morogoro, Tanzania," Southern African Forestry Journal, no. 200, pp. 49-60, 2004.

[25] R. E. Malimbwi and A. G. Mugasha, Reconnaissance Timber Inventory Report for Handeni Hill Forest Reserve in Handeni District, Tanzania for the Tanga Catchment Forest Project, FORCONSULT, Faculty of Forestry and Nature Conservation, Sokoine University of Agriculture, Morogoro, Tanzania, 2002.

[26] H. Nuru, C. D. K. Rubanza, and C. B. Nezia, "Governance of key players at district and village levels on health improvement of Urumwa Forest reserve, Tabora: ten years of Joint Forest Management," in Proceedings of the 1st Participatory Forest Management Research Workshop: Participatory Forest Management for Improved Forest Quality, Livelihood and Governance (PFM '09), pp. 111-122, 2009.
[27] A. De Gier, "Woody biomass assessment in woodland and shrub-lands," in Off-Forest Tree Resources of Africa, Proceedings of a Workshop, pp. 89-98, Arusha, Tanzania, 1999.

[28] S. Brown, "Measuring, monitoring and verification of carbon benefits for forest based projects," in Capturing Carbon and Conserving Biodiversity: The Market Approach, I. R. Swingland, Ed., pp. 118-133, Earthscan Publications, London, UK, 2003.

[29] K. MacDicken, "A guide to monitoring carbon storage in forestry and agroforestry projects," Tech. Rep. 1, Winrock International Institute for Agricultural Development, Arlington, Tex, USA, 1997.

[30] A. Martin, "Lessons for REDD from PES research," in REDD, Forest Governance and Rural Livelihoods: The Emerging Agenda, O. Springate-Baginski and E. Wollenberg, Eds., pp. 36-39, CIFOR, Bogor, Indonesia, 2010.

[31] I. Mustalahti, "Msitu wa Angai: haraka, haraka, haina baraka! Why does handing over the Angai forest to local villages proceed so slowly?" in Anomalies of Aid. A Festschrift for Juhani Koponen, J. Gould and L. Siitonen, Eds., vol. 15, pp. 168186, Institute of Development Studies, University of Helsinki, Helsinki, Finland, 2007.

[32] United Republic of Tanzania (URT), National Adaptation Programme of Action (NAPA), Vice President's Office, Division of Environment, 2007.

[33] FAO, Global Forest Resources Assessment 2005, Food and Agriculture Organization of the United Nations, Rome, Italy, 2006.

[34] B. K. Kaale and A. L. Simula, Contribution of Participatory Forest Management to Poverty Eradication in Liwale District, Lindi Region, Ministry of Natural Resources and Tourism. National Forest Programme Coordination Unit Support Programme, Dar es Salaam, Tanzania, 2004.

[35] T. Veltheim and M. Kijazi, "Lessons learned on participatory forest management," Tech. Rep. 61, East Usambara Conservation Area Management Programme, 2002.

[36] T. Blomley and H. Ramadhani, "Lessons learned from Participatory Forest Management in Tanzania (PFM)," SLSA Newsletter, no. 17, 2005.

[37] D. Murdiyarso and M. Skutsch, Community Forest Management as a Carbon Mitigation Option: Case Studies, CIFOR, Bogor, Indonesia, 2006.

[38] M. Skutsch, B. Karky, E. Zahabu, M. McCall, and G. PetersGuarin, Community Measurement of Carbon Stock Change for $R E D D$, Special study on forest degradation. Working paper 156, FAO, Rome, Italy, 2009.

[39] R. E. Malimbwi, J. Kielland-Lund, J. Nduwamung, and A. O. A. Chamshama, "Species diversity and standing crop development in four miombo vegetation communities," in Proceedings of the First Annual Forest Research Workshop, vol. 67, pp. 201212, Falcuty of Forest, 1998.

[40] E. J. Luoga, The effect of human disturbances on diversity and dynamics of Eastern Tanzania Miom $\neg$ bo arborescent species, Ph.D. thesis, Faculty of Science, University of the Witwaterrand, Johannesburg, South Africa, 2000.

[41] J. M. Abdallah, Assessment of the impact of non-timber forest products utilization on sustainable management of Miombo woodlands in Urumwa Forest Reserve, Tabora, Tanzania, M.S. thesis, Sokoine University of Agriculture, Morogoro, Tanzania, 2001.

[42] I. Backéus, B. Pettersson, L. Strömquist, and C. Ruffo, "Tree communities and structural dynamics in miombo (Brachystegia-Julbernardia) woodland, Tanzania," Forest Ecology and Management, vol. 230, no. 1-3, pp. 171-178, 2006. 
[43] J. Isango, M. Varmola, S. Valkonen, and S. Tapaninen, "Stand structure and tree species composition of Tanzania miombo woodlands: a case study from miombo woodlands of community-based forest management in Iringa District," in Proceedings of the 1st MITIMIOMBO Project Workshop, pp. 4356, Finnish Forest Research Institute, Morogoro, Tanzania, 2007. 

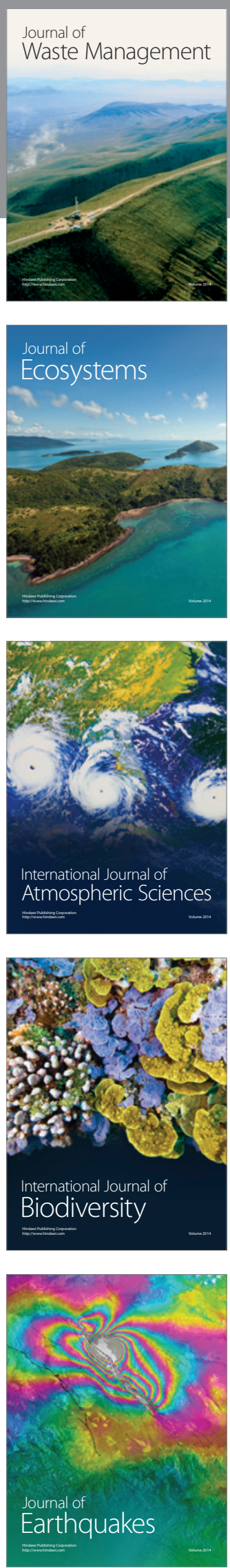
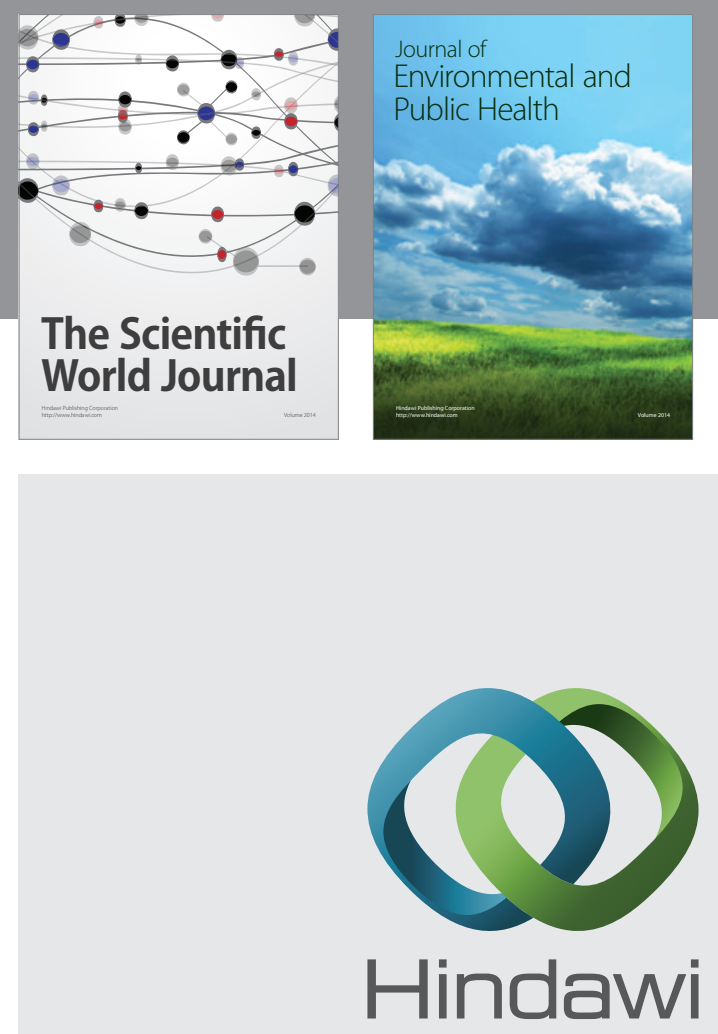

Submit your manuscripts at

http://www.hindawi.com
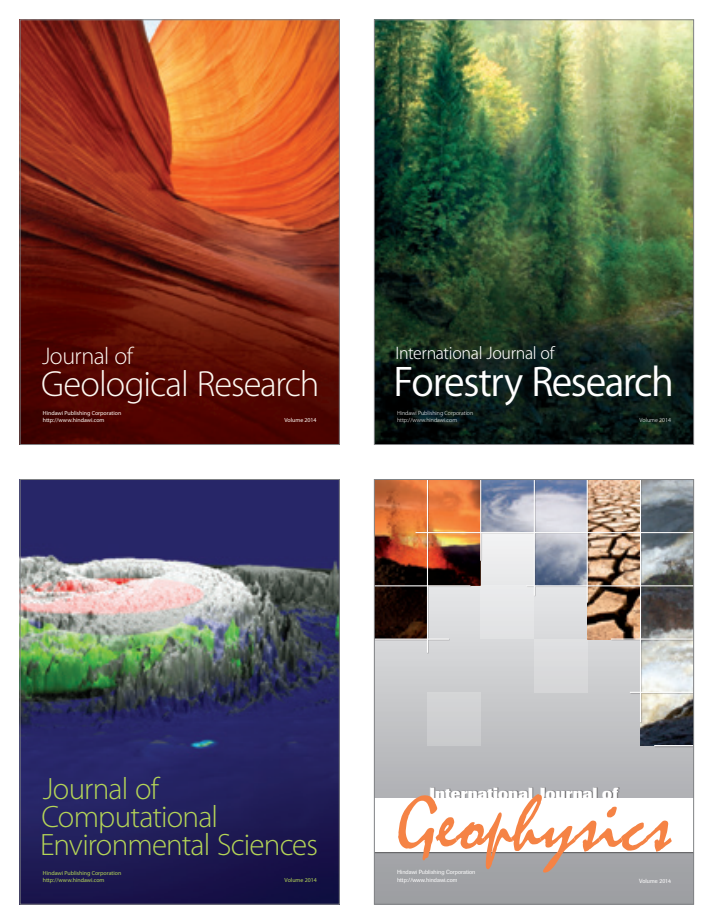
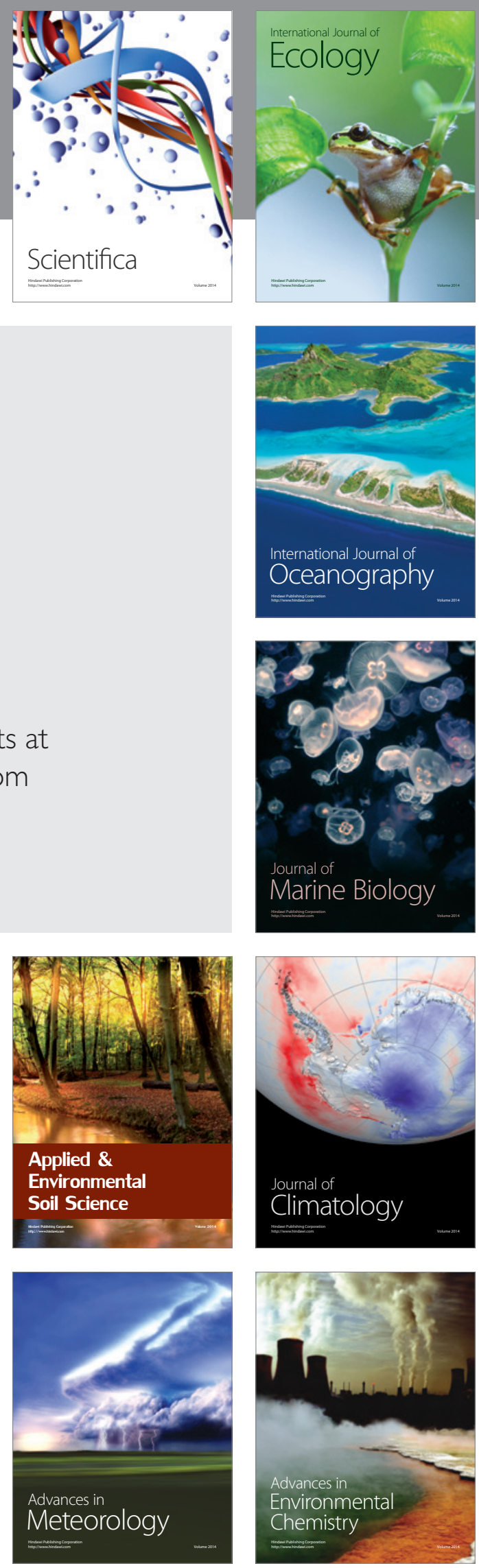